\title{
Metabolic activities and health indices of African catfish (Clarias gariepinus) fed varying levels of Zingiber officinale root
}

\author{
Adegbesan Sherifat Ibidunni*, Obasa Samuel Olubodun, Abdulraheem Ikililu \\ Department of Aquaculture \& Fisheries Management, College of Environmental Resources Management, Federal University of Agriculture, Abeokuta \\ (FUNAAB), P.M.B 2240, Abeokuta, Ogun State, Nigeria.
}

\section{ARTICLE INFO}

Article history:

Received on: 08/02/2017

Accepted on: 12/05/2017

Available online: 14/08/2017

Key words:

Growth, ginger root-powder,

metabolism, health, dietary

supplement, Clarias

gariepinus.

\begin{abstract}
Growth, haematology and histopathology are important indices in evaluating the health and physiological state of fish. These metabolic and health indices were examined in Clarias gariepinus fed with Zingiber officinale (ginger) roots- powder supplemented diets in 40-litre freshwater-filled plastic tanks. 120 C. gariepinus fingerlings (weight, $2.33 \pm 0.07 \mathrm{~g}$ ) were fed with $40 \%$ crude protein diets containing three concentrations of Zingiber officinale roots-powder: GRP1-1\%; GRP2-2\%; GRP3-3\%, and control-0\% ad libitum twice daily for 12 weeks. Significant differences $(\mathrm{p}<0.05)$ occurred in the growth parameters except feed conversion ratio and specific growth rate. Survival rate decreased as concentration of powder increased. Differences $(\mathrm{p}<0.05)$ seen in packed cell volume (PCV), Haemoglobin $(\mathrm{Hb})$, and Red blood cell (RBC), thus highest in GRP3: PCV $(37.00 \pm 1.16 \%), \mathrm{Hb}(12.37 \pm 0.37 \mathrm{~g} / \mathrm{dl})$ and $\mathrm{RBC}\left(3.47 \pm 0.08 \times 10^{6} / \mathrm{l}\right)$ and lowest in control: PCV $(22.00 \pm 0.58 \%)$, $\mathrm{Hb}(7.37 \pm 0.20 \mathrm{~g} / \mathrm{dl})$ and $\mathrm{RBC}\left(2.07 \pm 0.06 \times 10^{6} / \mathrm{l}\right)$. Liver histology of control fish was normal, while fatty degenerations were seen in the treated fish. The histology of fish kidney was normal in all treatments. The study concluded that $1 \%$ ginger root-powder dietary supplementation in cultured C. gariepinus could effectively improve the metabolic activities, health profile and survival of the fish.
\end{abstract}

\section{INTRODUCTION}

Aquaculture is one of the most rapid growing food producing sectors in the world [1]. thus as it is an emerging, growing industrial sector, it requires continued research with scientific, technical developments and innovations in the different aspect of production including the search for natural alternative growth promoters to be used in fish feeds [2]. In this respect, so many work have been done in developing new dietary supplementation strategies in which various health and growth promoting compounds like probiotics, prebiotics, synbiotics, phytobiotics and other important dietary supplements have been used [3]. In aquaculture, the method of increasing the defense mechanism and disease management in fish is through prophylactic administration of immunostimulants in the fish [4], this has drawn the attention of fish nutritionists to the immuneprotection of fish besides the growth as sustainable a quaculture

\section{* Corresponding Author}

Adegbesan Sherifat Ibidunni, Department of Aquaculture \& Fisheries Management, College of Environmental Resources Management, Federal University of Agriculture, Abeokuta (FUNAAB), P.M.B 2240, Abeokuta, Ogun State, Nigeria. Email: ibidunnisherifat @ ahoo.co.uk depends on perfect balance between growth and health condition of fish. Hematological parameters are necessary in evaluating the physiological condition and nutritional state of fish [5], histopathological alterations in fish liver and kidney are important indicators of chemical toxicity, and it is away to know the effects of exposure of aquatic animals to toxins present in the aquatic environment [6-8]. Ginger (Zingiber officinale) belongs to the Zingiberaceae plant; it is a spice and the rhizome of the $Z$. officinale is seen and known in every part of the World and is eaten whole as a delicacy or as spice in foods such as fish $[9,10]$. The root contains several chemical compounds such as starch $(50 \%)$, protein $(9 \%)$, lipids, protease $(2.26 \%)$ and volatile oils. It also contains vitamins $\mathrm{A}$ and vitamin $\mathrm{B}_{3}$ (niacin) [11]. Ginger rhizome contains different active ingredients, these include; ginger oil and gingerols, which can be converted to shogaols, zingerone and paradol [12]. Z. officinale root is important to growth and immune systems in aquatic animals [13], it is important in fish diet in that it control infection, proliferation in the numbers of neutrophils, macrophages and lymphocytes and enhanced phagocytic and lysozyme activity [14]. Hence, this study aims at determining the growth promoting activity; metabolic activities and health profile of cultured Clarias gariepinus (Burchell 1822) fed different concentrations of $Z$. officinale (ginger) root-powder. 


\section{MATERIALS AND METHODS}

\subsection{Experimental system}

The research work was done at the fish farm (hatchery unit) of the Department of Aquaculture and Fisheries Management, College of Environmental Resources Management, Federal University of Agriculture, Abeokuta, Ogun State, Nigeria from April 2015 to September 2015. The feeding trial was conducted in twelve (12) rectangular plastic tanks each with a capacity of 60 litres of fresh water and each tank was two-third filled (40 litres).

\subsection{Experimental fish}

African mud catfish (C.gariepinus) fingerlings of mean weight $2.33 \mathrm{~g}$ were used as the test fish species in this study. A total of one hundred and twenty (120) fingerlings were purchased at Motherhood Fish Farm, Abeokuta, Ogun State, Nigeria. The fish were randomly (completely randomized design) allotted into four (4) treatments in the plastic tanks at a stocking rate of ten fingerlings per tank in triplicates.

\subsection{Experimental diets}

The experimental diets are made up of three treatment diets containing different concentrations of ginger root-powder and the control as listed below:

Treatment 1 (Control) - 0\% ginger root-powder

Treatment 2 (GRP1) - 1\% ginger root-powder

Treatment 3 (GRP2) - 2\% ginger root-powder

Treatment 4 (GRP4) - 3\% ginger root-powder

\subsubsection{Diets formulation and preparation}

A ration of $40 \%$ crude protein (CP) containing fishmeal $(72 \% \mathrm{CP})$, soybean meal $(42 \% \mathrm{CP})$, groundnut cake $(45 \% \mathrm{CP})$, using yellow maize $(10 \% \mathrm{CP})$ as the energy source and fixed ingredients including vitamin premix (1\%), lysine $(0.5 \%)$, methionine $(0.5 \%)$, di calcium phosphate $(0.5 \%)$; salt $(0.5 \%)$ and vegetable oil $(4.0 \%)$. The required weight of each ingredient was calculated using Pearson Square method using the stipulated crude protein requirement of the fish. All the four diets formulated were carefully prepared which involves measuring the ingredients, thoroughly mixing the ingredients, and pelletizing them. The ginger rhizome was prepared separately before incorporation into the basal diets.

\subsubsection{Preparation and processing of ginger roots powder}

Fresh rhizomes of ginger roots were purchased from a local market in Abeokuta, Ogun state, Nigeria and were confirmed by a botanist. The plant was dried in the shade. The dried rhizomes were further crushed into powdered form mechanically using a household grinder and sieved using a household sieve as described by [15].

\subsubsection{Incorporation of ginger roots powder into the diets}

The powdered ginger produced was mixed directly with the basal diet. Ginger root powder was added into the diets at concentration of $1 \%, 2 \%$, and $3 \%$ of feed. Compounded feeds were pelletized $(2 \mathrm{~mm})$ using the pelletizing machine from University fish farm, sun dried, allow to cool in an open air, packed and stored in an opaque nylon bag according to the treatments. The percentage of all the feed ingredients used in formulating the four experimental diets is listed in Table 1.

Table 1: Feed ingredients \& Proximate Compositions of the Experimental Diets (\% Dry weight).

\begin{tabular}{lcccc}
\hline Ingredients (\%) & Control & GRP1 & GRP2 & GRP3 \\
\hline Fishmeal & 31.2 & 31.2 & 31.2 & 31.2 \\
Soybean meal & 15.6 & 15.6 & 15.6 & 15.6 \\
Groundnut cake & 15.6 & 15.6 & 15.6 & 15.6 \\
Yellow Maize & 30.5 & 30.5 & 28.75 & 27.75 \\
Vitamin Premix & 1.0 & 1.0 & 1.0 & 1.0 \\
Lysine & 0.5 & 0.5 & 0.5 & 0.5 \\
Salt & 0.5 & 0.5 & 0.5 & 0.5 \\
Vegetable Oil & 4.0 & 4.0 & 4.0 & 4.0 \\
Methionine & 0.5 & 0.5 & 0.5 & 0.5 \\
DCP & 0.5 & 0.5 & 0.5 & 0.5 \\
Ginger root-powder & 0.0 & 1.0 & 2.0 & 3.0 \\
TOTAL & 100 & 100 & 100 & 100 \\
Moisture & 10.50 & 10.98 & 9.86 & 9.56 \\
Crude protein & 40.01 & 40.00 & 40.04 & 39.98 \\
Fibre content & 3.10 & 3.12 & 3.04 & 3.42 \\
Ash & 5.20 & 4.45 & 3.95 & 3.74 \\
Ether extract & 5.42 & 5.20 & 4.98 & 4.70 \\
Nitrogen free extract & 35.77 & 36.25 & 38.13 & 38.60 \\
\hline
\end{tabular}

$\mathrm{DCP}=$ Di calcium phosphate

\subsubsection{Proximate analysis}

The Proximate analysis of the four diets formulated and the fish were carried out following procedure as described by [16].

\subsection{Experimental procedure}

The fish were acclimated to the experimental system for a period of 14 days before the commencement of the feeding trial and were fed two times daily with a commercial diet (40\% CP). The fish were weighed in batches; ten per treatments at the beginning of the experiment. The operating temperature, ph and the dissolved oxygen are $25^{\circ} \mathrm{C}, 6.00$ and $6.66 \mathrm{Mg} / \mathrm{L}$ respectively.

\subsubsection{Fish feeding}

Prior to the commencement of the experiment, all fish were starved for 24 hours to eliminate variation in weight due to residue food in the gut and at the same time to increase the appetite of the fish. Fish were fed with the diets at two feeding regimes, in the morning between 08:00 - 09:00h and evening between 17:00 - 18:00h, ad libitum for (84 days) 12 weeks.

\subsubsection{Water quality management}

In the course of the experiment, water temperature $\left({ }^{\circ} \mathrm{C}\right)$ and dissolved oxygen (mgl) were measured every week using a combined digital YSI dissolved oxygen meter (YSI Model 57, Yellow Spring Ohio); $\mathrm{pH}$ was monitored weekly using $\mathrm{pH}$ meter (Mettler Toledo-320, Jenway UK). 
Table 2: Proximate compositions of the fish ( $\%$ Dry weight) (Mean \pm SD)

\begin{tabular}{|c|c|c|c|c|c|}
\hline Proximate components (\%) & Initial & Control $(0 \%)$ & GRP1 (1\%) & GRP2 (2\%) & GRP3 (3\%) \\
\hline Moisture & 11.54 & $11.84 \pm 0.23^{\mathrm{b}}$ & $11.92 \pm 0.02^{\mathrm{a}}$ & $11.85 \pm 0.03^{\mathrm{a}}$ & $11.97 \pm 0.04^{\mathrm{a}}$ \\
\hline Crude protein & 43.50 & $47.37 \pm 0.55^{\mathrm{c}}$ & $52.48 \pm 0.65^{\mathrm{a}}$ & $50.83 \pm 0.17^{\mathrm{b}}$ & $50.19 \pm 0.38^{\mathrm{b}}$ \\
\hline Fibre content & 0.90 & $1.23 \pm 0.02^{\mathrm{c}}$ & $1.34 \pm 0.05^{\mathrm{b}}$ & $1.60 \pm 0.12^{\mathrm{a}}$ & $1.39 \pm 0.04^{\mathrm{b}}$ \\
\hline Ash & 0.98 & $4.18 \pm 0.31^{\mathrm{a}}$ & $3.83 \pm 0.13^{b}$ & $3.49 \pm 0.01^{\mathrm{b}}$ & $3.57 \pm 0.04^{\mathrm{b}}$ \\
\hline Ether extract & 8.50 & $12.44 \pm 0.08^{\mathrm{a}}$ & $9.85 \pm 0.20^{\mathrm{b}}$ & $10.01 \pm 0.28^{\mathrm{b}}$ & $9.58 \pm 0.06^{\mathrm{b}}$ \\
\hline Nitrogen free extract & 34.58 & $22.95 \pm 0.09^{\mathrm{a}}$ & $19.58 \pm 0.38^{\mathrm{c}}$ & $21.22 \pm 0.60^{\mathrm{b}}$ & $23.30 \pm 0.36^{\mathrm{a}}$ \\
\hline
\end{tabular}

Means along the same row with same letter are not significantly different $(\mathrm{p}>0.05)$

\subsection{Monitoring of fish growth}

The fish were weighed in each tank weekly using a sensitive electronic weighing scale (Mettler Toledo FB602, Jenway UK) to monitor the fish growth and ensure adequate feed consumption. Mortality was monitored daily.

\subsection{Blood collection and haematological analysis}

The blood samples were taken from the caudal fin of the fish following the procedure of [17]. The blood samples were taken to microbiology laboratory of College of Veterinary Medicine (COLVET), FUNAAB for haematological analysis. The blood samples were analyzed according to methods adopted in fish haematology[18][19][20]. The haematological parameters that were analyzed include packed cell volume (PCV) or Haematocrit (HCT), Haemoglobin ( $\mathrm{Hb}$ ) and Red blood cell (RBC). The absolute red blood cell indices (Mean cell haemoglobin $(\mathrm{MCH})$, Mean cell volume (MCV), and mean cell haemoglobin concentrations (MCHC) were calculated. The white blood cell (WBC) and differential count (neutrophils and lymphocytes) were analyzed as described [21].

\subsection{Histopathology analysis}

The histopathological examinations were carried out on the liver and kidney of the fish at the Department of Veterinary Pathology, COLVET, FUNAAB. The organs were carefully removed from the body of the fish so as to avoid damage. They were preserved at $10 \%$ formalin. The fixed tissues were processed routinely for histological analysis as described by [22]. Necrotized areas were then photographed and read accordingly to determine the histopathology effect of ginger root-powder.

\subsection{Data analysis}

\subsubsection{Analysis of fish growth performance}

Growth performance of fish was determined following the methods as illustrated by [23] in term of final mean bodyweight, survival (\%), specific growth rate, (SGR, \%/day). The following growth parameters were calculated at the end of the study:

Percentage weight gain PWG $(\%)=\frac{\text { Final mean body weight }}{\text { Initial mean body weight }} \times 100$

$$
\mathrm{SGR}=\frac{L_{n} W_{2}-L_{n} W_{1}}{\text { Time }(\text { days of experiment })} \times 100
$$

Where, $\quad \mathrm{W}_{1}=$ Initial weight gained;

$\mathrm{W}_{2}=$ Final weight gained;

$\mathrm{L}_{\mathrm{n}}=$ Natural logarithm
Survival rate $=\frac{\text { No of fish remaining at the end of the experiment }}{\text { No of fish at the beginning of the experiment }} \times 100$

Mean weight gain $(\mathrm{MWG})=$ Final weight $(\mathrm{g})$ of fish - Initial weight $(\mathrm{g})$ of fish

Feed conversion ratio $(\mathrm{FCR})=\frac{\text { Dry Weight of feed fed }(g)}{\text { Fish Weight gained }}$

Also, data were obtained from the haematology parameters.

\subsubsection{Statistical analysis}

All data obtained were subjected to one way analysis of variance (ANOVA). Duncan Multiple Range Test [24] was used for comparison among diets means at a significance level of 0.05 ( $\mathrm{p}<0.05)$. The computations were subjected to SAS statistical software version 15 .

\section{RESULTS AND DISCUSSION}

\subsection{Proximate composition of experimental diets}

Proximate compositions of the four diets formulated and prepared for the feeding trial are presented in Table 1.

\subsection{Carcass compositions of experimental fish}

The initial and final carcass compositions of the fish fed with varying levels of ginger root-powder and the control is presented in Table 2.

Table 3: Physicochemical Parameters of water during experimental period.

\begin{tabular}{cccc}
\hline Week & Ph & Dissolved Oxygen $(\mathbf{M g} / \mathbf{L})$ & Temperature $\left({ }^{\mathbf{0}} \mathbf{C}\right)$ \\
\hline 0 & 6.00 & 6.10 & 25.00 \\
1 & 6.90 & 6.20 & 25.41 \\
2 & 7.15 & 6.18 & 25.60 \\
3 & 7.03 & 6.24 & 25.78 \\
4 & 7.34 & 6.35 & 25.83 \\
5 & 7.41 & 6.50 & 25.61 \\
6 & 7.48 & 7.21 & 26.13 \\
7 & 7.31 & 7.25 & 25.53 \\
8 & 7.22 & 7.40 & 26.20 \\
9 & 7.28 & 7.56 & 26.13 \\
10 & 7.50 & 7.45 & 26.30 \\
11 & 7.55 & 7.61 & 26.05 \\
12 & 7.56 & 7.70 & 26.02 \\
\hline
\end{tabular}

\subsection{Physicochemical parameters of the water}

The physicochemical parameters of the water recorded during the experimental period are shown in Table 3 . The values of the physico-chemical parameters observed in the experimental tanks during this study were within the range recommended for $C$. gariepinus [25] [26]. The achievement of this was as a result of optimum water management practices. 
Table 4: Growth performance and nutrient utilization of Clariasgariepinusfed ginger root-powder supplemented diets (Mean \pm SD).

\begin{tabular}{|c|c|c|c|c|}
\hline Parameters & Control (0\%) & GRP1 (1\%) & GRP2 (2\%) & GRP3 (3\%) \\
\hline Initial weight (g) & $2.30 \pm 0.06^{\mathrm{a}}$ & $2.33 \pm 0.09^{\mathrm{a}}$ & $2.33 \pm 0.03^{\mathrm{a}}$ & $2.33 \pm 0.09^{\mathrm{a}}$ \\
\hline Final weight $(\mathrm{g})$ & $14.22 \pm 1.12^{\mathrm{c}}$ & $20.27 \pm 0.92^{\mathrm{a}}$ & $18.49 \pm 1.09^{\mathrm{b}}$ & $20.14 \pm 1.15^{\mathrm{a}}$ \\
\hline Weight gain $(\mathrm{g})$ & $11.92 \pm 1.16^{\mathrm{c}}$ & $17.95 \pm 0.90^{\mathrm{a}}$ & $16.15 \pm 1.06^{\mathrm{b}}$ & $17.82 \pm 1.07^{\mathrm{a}}$ \\
\hline Percentage Weight gain (\%) & $518.3 \pm 10.21^{\mathrm{c}}$ & $840.8 \pm 7.70^{\mathrm{a}}$ & $691.4 \pm 10.63^{\mathrm{cb}}$ & $762.3 \pm 17.69^{b}$ \\
\hline Feed conversion ratio & $1.40 \pm 0.07^{\mathrm{b}}$ & $1.57 \pm 0.04^{\mathrm{a}}$ & $1.56 \pm 0.02^{\mathrm{a}}$ & $1.55 \pm 0.02^{\mathrm{a}}$ \\
\hline Specific growth rate (\%/day) & $2.31 \pm 0.19^{\mathrm{b}}$ & $2.57 \pm 0.10^{\mathrm{a}}$ & $2.46 \pm 0.06^{\mathrm{a}}$ & $2.56 \pm 0.02^{\mathrm{a}}$ \\
\hline Survival rate $(\%)$ & $86.67 \pm 8.82^{\mathrm{a}}$ & $80.00 \pm 5.77^{\mathrm{b}}$ & $63.33 \pm 3.33^{\mathrm{c}}$ & $63.33 \pm 3.33^{\mathrm{c}}$ \\
\hline
\end{tabular}

Means along the same row with same letter are not significantly different ( $>0.05)$.

\subsection{Growth performance}

The growth performance and nutrient utilization of $C$. gariepinus fed ginger root-powder at three varying levels of dietary supplementation is shown in Table 3. There was a general increase in weight gain in the course of the experiment with the highest growth performance observed in fish fed $1 \%$ and $3 \%$ ginger root-powder. This is in agreement with the work of [27] who recorded similar increase in weight gain of fish when fed diets supplemented with Walnut leaf and Onion bulb residues. This was corroborated by the work of [28] who showed that supplementation of garlic improves the performance of broilers when added at the rate of $1 \%$ and can be an alternative to antibiotic growth promoter in the feeding of broiler chicken. The increase in the growth rate of $C$. gariepinus in the first few weeks of culture in the study may be due to initial starvation of the fish which made them more metabolically active, which is similar to [29] observation in juvenile Heterotis niloticus. They recorded an increase in growth of the fish as they were subjected to delay in feed distribution. The superior performances of fish fed the supplemented diets in PWG and SGR over control diet could be due to the presence of growth promoters, stimulants or constituents in ginger root-powder (Zingiberene, Glycosides, Terpenoids,).This is in accord with the result of [30] who found that inclusion of Aloe vera leaves up to $2 \%$ in the diet showed better growth performance of Fayoumi chicks. This was corroborated by [31] who demonstrated that high levels $(2 \%)$ of Aloe vera had a positive effect on growth performance in rainbow trout. Also, [32] suggested that ginger and garlic supplements collectively or individually improved growth performance of broilers. This was corroborated by [15]. The increased FCR recorded in fish fed supplemented diets than the control is similar to the report of [27] who revealed that inclusion of $1.5 \%$ walnut leaf increased FCR in the supplemented groups than the control. This was also corroborated by [33] which showed that the addition of Propolis ethanolic extract and crude propolis increased the FCR, FER and PER in the supplemented groups when compared with the control. The findings of [34] who showed that were no significant differences $(\mathrm{P}>0.05)$ in FCR among all dietary ginger powder treatments which conformed to the result obtained in this study. According to [35] feed conversion ratio is between 1.2-1.8 for fish fed carefully prepared diets, and the results from the present study fall within this range. The better SGR recorded in the supplemented diets is in correlation with the result of [36] which showed that Allium sativum supplementation positively affected $O$. niloticusbiomass and specific growth rate (SGR).

The reduction in survival rate in fish fed the supplemented diets as recorded in this experiment could be as a result of some phytochemicals inherent in it. This result of this present study disagreed with the findings of [37] who concluded that survival rate of fish was promoted in diets supplemented with Mellisa officinalis and Aloe vera. Fish fed 2\% and 3\% ginger roots powder recorded the highest mortality rate. The findings of [38] also revealed that the mortality rate of fish fed untreated ginger peel increased with respect to the different concentrations and the highest concentration having more mortality rate.

\subsection{Haematological indices of fish}

The haematological indices of fish fed varying levels of ginger root-powder and the control diets is shown in Table 5.Haematological components of blood are important in monitoring feed toxicity especially with feed constituents that affect the formation of blood in culture fisheries [39].The present study indicates that $C$. gariepinus fed ginger root-powder for 12 weeks showed significant $(p<0.05)$ increase in haematocrit (PCV), haemoglobin, red blood cell (RBC), white blood cell (WBC), except for WBC of $2 \%$ inclusion of GRP in comparison to the control ( $\mathrm{p}<0.05)$. This is in agreement with the work of [15] who observed similar increase in the haematological parameters in rainbow trout fed ginger powder. This is corroborated with the findings of [40] who indicated that inclusion of ginger root powder in cock diet at level of $1 \%$ improved haematological profile of the cork. These are also similar to the findings of [36] who reported significant enhancement (higher values) of WBC and PCV in diet supplemented with Mellisa officinalis and aloe vera.

The increased WBC and lymphocytes as the level of inclusion in the blood of fish fed ginger powder increased in this study (Table 5) may be attributed to increased production of leucocytes in the hematopoietic tissue of the liver. This agreed with the work of [41] who also recorded similar increase in WBC and lymphocytes in the blood of $C$. carpio fed aloe vera. The WBC and lymphocytes are the defense cells of the body [42]. Demonstrated that the amount of WBC and lymphocytes in the blood has implication in the immune responses of the animal and the ability of the animal to fight infection. High WBC count is usually associated with microbial infection or circulating system [38]. 
Table 5: Haematological parameters of Clarias gariepinus fed ginger root-powder supplemented diets (Means \pm SD).

\begin{tabular}{|c|c|c|c|c|}
\hline Parameters & Control (0\%) & GRP1 (1\%) & GRP2 $(2 \%)$ & GRP3 (3\%) \\
\hline$\overline{\mathrm{PCV}(\%)}$ & $22.00 \pm 0.58^{\mathrm{d}}$ & $29.00 \pm 1.16^{\mathrm{d}}$ & $25.00 \pm 1.16^{\mathrm{f}}$ & $37.00 \pm 1.16^{\mathrm{a}}$ \\
\hline $\mathrm{Hb}(\mathrm{g} / \mathrm{dl})$ & $7.37 \pm 0.20^{\mathrm{d}}$ & $9.67 \pm 0.38^{\mathrm{b}}$ & $8.37 \pm 0.38^{c}$ & $12.37 \pm 0.38^{\mathrm{a}}$ \\
\hline $\mathrm{RBC}\left(\mathrm{x} 10^{6} / 1\right)$ & $2.07 \pm 0.06^{\mathrm{d}}$ & $2.74 \pm 0.12^{\mathrm{b}}$ & $2.36 \pm 0.11^{\mathrm{c}}$ & $3.47 \pm 0.08^{\mathrm{a}}$ \\
\hline $\mathrm{MCH}(\mathrm{pg})$ & $35.60 \pm 0.07$ & $35.30 \pm 0.15$ & $35.39 \pm 0.06$ & $35.58 \pm 0.25$ \\
\hline $\operatorname{MCHC}(\mathrm{g} / \mathrm{dl})$ & $33.33 \pm 0.00$ & $33.05 \pm 0.78$ & $33.41 \pm 0.04$ & $33.38 \pm 0.03$ \\
\hline $\operatorname{MCV}(\mathrm{fl})$ & $10.71 \pm 0.03$ & $10.61 \pm 0.04$ & $10.60 \pm 0.00$ & $10.66 \pm 0.08$ \\
\hline $\mathrm{WBC}\left(\mathrm{x} 10^{3}\right)$ & $11.20 \pm 0.52^{\mathrm{b}}$ & $9.97 \pm 0.32^{\mathrm{c}}$ & $11.97 \pm 1.01^{\mathrm{b}}$ & $12.70 \pm 0.81^{\mathrm{a}}$ \\
\hline Neutrophils (\%) & $40.00 \pm 1.73^{\mathrm{a}}$ & $40.00 \pm 1.16^{\mathrm{b}}$ & $50.67 \pm 0.33^{\mathrm{a}}$ & $38.67 \pm 1.45^{\mathrm{c}}$ \\
\hline Lymphocytes (\%) & $56.67 \pm 1.45^{\mathrm{b}}$ & $56.00 \pm 1.16^{\mathrm{d}}$ & $64.67 \pm 0.33^{\mathrm{a}}$ & $59.00 \pm 0.58^{\mathrm{c}}$ \\
\hline Eosinophils (\%) & $3.00 \pm 0.00^{\mathrm{a}}$ & $3.67 \pm 0.33^{\mathrm{a}}$ & $2.67 \pm 0.33^{\mathrm{b}}$ & $2.00 \pm 0.58^{\mathrm{b}}$ \\
\hline Monocytes (\%) & $0.67 \pm 0.33$ & $0.67 \pm 0.33$ & $0.67 \pm 0.33$ & $0.67 \pm 0.33$ \\
\hline Basophils (\%) & $0.00 \pm 0.00$ & $0.00 \pm 0.00$ & $0.00 \pm 0.00$ & $0.00 \pm 0.00$ \\
\hline
\end{tabular}

Means along the same row with same letter are not significantly different ( $>0.05)$.

The range of $\mathrm{RBC}\left(2.07 \times 10^{6}\right.$ to $\left.3.47 \times 10^{6} \mathrm{~mm}^{3}\right)$ recorded in this study is comparable with $2.24 \mathrm{X} 10^{6}$ to $2.49 \mathrm{X}$ $10^{6} \mathrm{~mm}^{3}$ reported by [43] in a study on growth performance and haematology of Clarias gariepinus fed varying inclusion of Leucaena leucocephala leaf meal. Reduction in the red blood cells was observed in fish fed GRP2 could be ascribed to the higher concentration of anti-metabolites especially tannin. This is in agreement with the work of [44] who observed similar decrease in RBC in fish fed higher level of M. oleifera leaf meal.

There were no significant difference in $\mathrm{MCH}, \mathrm{MCHC}$ and MCV observed in fish fed varying levels of ginger rootpowder. This is in correlation with [15] who observed no significant difference in MCV value in ginger powder fed diet and control.

\subsection{Histopathology of the fish \\ 3.6.1 Histology of the liver of C. gariepinus}

The histological sections of fish fed varying levels of ginger root-powder and the control are presented in Figures 1-4. Vacuolar degenerations were observed in the fish livers from the ginger root-powder supplemented diets (Figures 2-4).The histopathology of the liver of fish fed with control diet showed that the liver was normal with mild fatty change. The mild fatty change might be attributed to the high fat content of catfishes. Fish fed GRP1 revealed normal liver but there is mild fatty change and vacuolar degeneration. This is in agreement with the report of [45] who observed vacuolation in fish livers fed $M$. oleiferadiet treatment and the control. Also, histological sections of the liver of fish fed GRP2 and GRP3 indicated fish health was compromised at the higher doses. This is corroborated with the finding of [37] who revealed that liver of fish fed $30 \%$ untreated ginger peel had a severe fatty change. The presence of diffuse vacuolar degeneration of hepatocytes in fish fed varying levels of ginger root-powder may be as a result of excessive work required by the fish's liver to get rid of the plant toxicant from its body during the process of detoxification. This is corroborated by the work of [46] who revealed similar effect on the fish liver.

However, vacuolar degeneration is a morphopathological alteration of the gastro-intestinal tract, and it may be associated with toxins and or infection, which causes significant loss of water and potassium. Steatosis (lipid accumulated in the liver cells) could be present when there is excessive fat to be metabolized, or the lipid function of the liver cells are impaired due to hypoxia, toxic damage or certain infectious diseases [47]. Both vacuolar degeneration and fatty degeneration are reversible injuries, and cells can recover their normal functions (homeostasis) when the stress is removed [47]. However, the recovery of cells will depend on the severity and duration of exposure to the stressors.

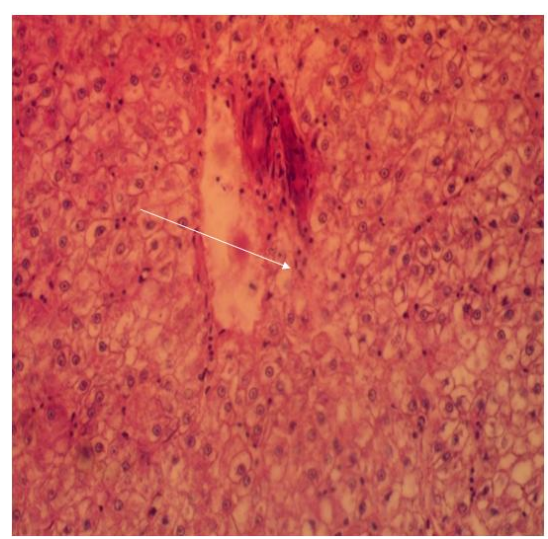

Fig. 1: Histological section of liver of fish fed with control diet. Figure 1 presents fragment of the liver tissue showing regular hepatocyte in cords and plates with normal portal tract and central vein.

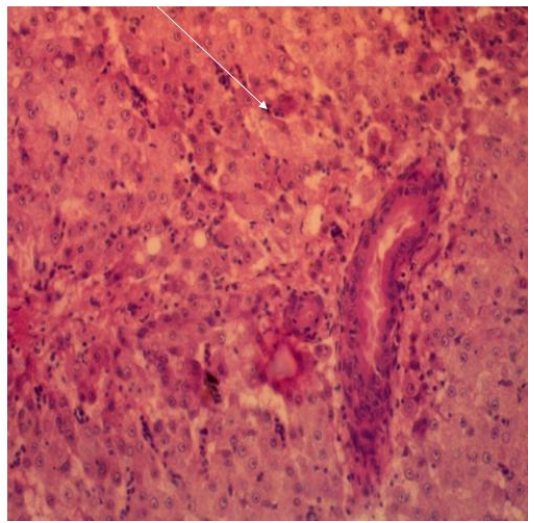

Fig. 2: Histological section of liver of fish fed $1 \%$ ginger root-powder. Liver tissue shows acinar formation and moderate infiltration of the hepotocyte cytoplasm by lobules of matured adipocytes, there was also vacuolar degeneration of the hepatocytes. 


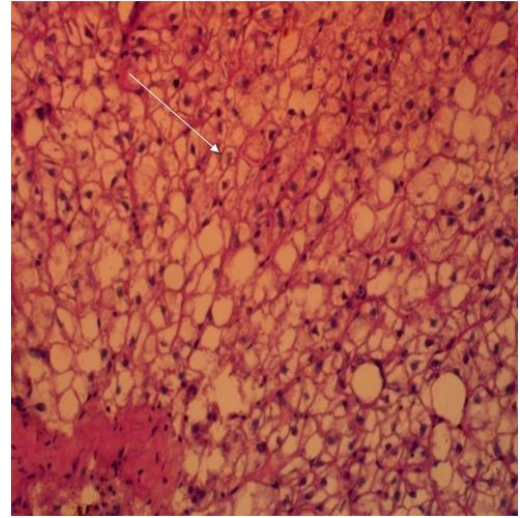

Fig. 3: Histological section of liver of fish fed $2 \%$ ginger root-powder. This figure revealed moderate and diffuse vacuolar fatty degeneration of the hepatocyte and intense infiltration of the hepatocyte cytoplasm with by lobules of matured adipocytes.

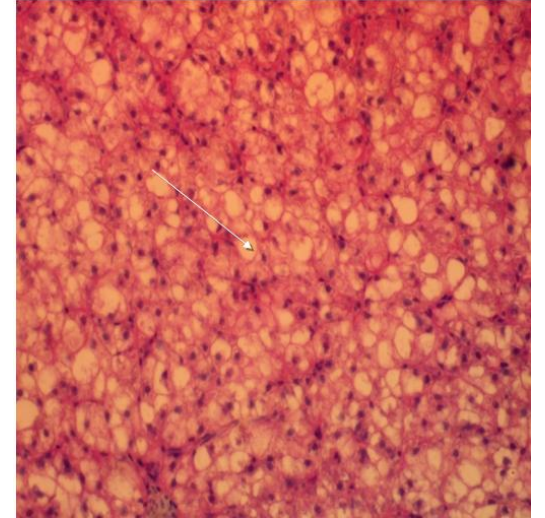

Fig. 4: Histological section of liver of fish fed $3 \%$ ginger root-powder. It shows that there was moderate and diffuse vacuolar degeneration of the hepatocytes, there are areas of necrosis and fibrous connective tissues proliferation, while some parts show hepatocyte with intra-cytoplasmic infiltration by matured adipocytes.

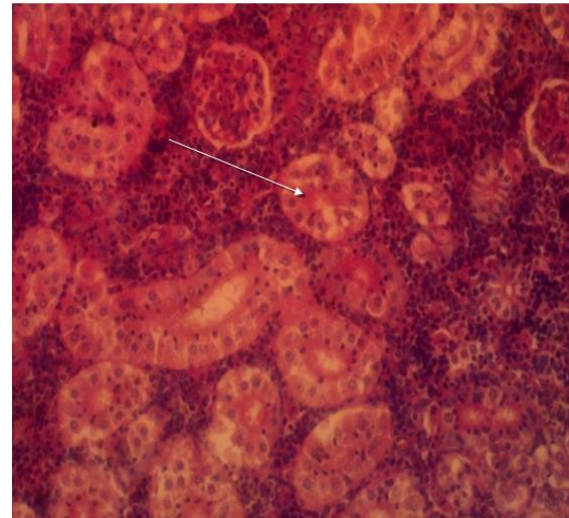

Fig. 5: Histological section of kidney of fish fed control diet. This figure revealed kidney tissues with regular epithelial cells and no physical damage done to the tissues.

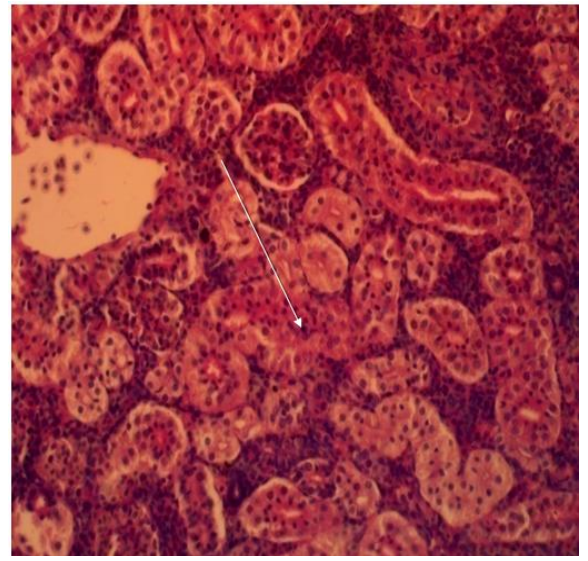

Fig. 6: Histological section of kidney of fish fed $1 \%$ ginger roots powder, which revealed that the kidney tubules are regular with no visible lesion.

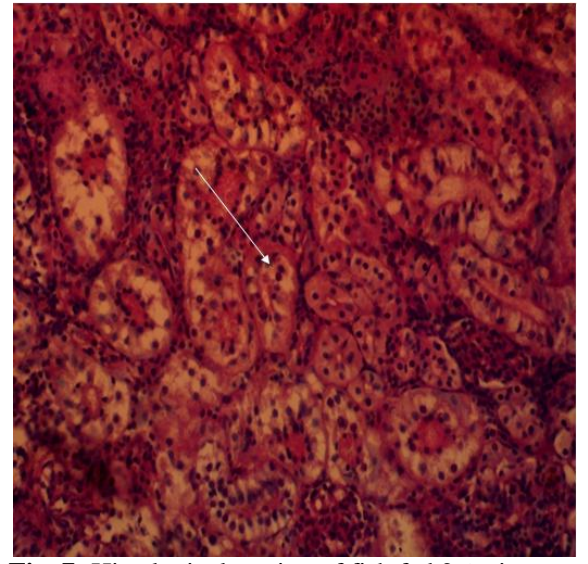

Fig. 7: Histological section of fish fed 2\% ginger root-powder. It shows that there was mild diffuse vacuolar degeneration of the tubules in the kidney tissue.

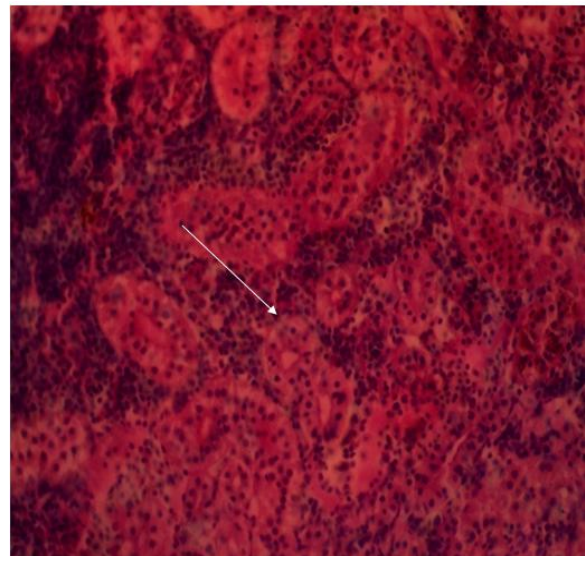

Fig 8: Histological sections of fish fed 3\% ginger roots powder. This figure revealed that the kidney tubules are regular with no visible lesion.

\subsubsection{Histology of the kidney of C. gariepinus}

The histological sections of the kidney of fish fed varying levels of ginger root-powder and the control are shown in Figures 5-8. The absence of visible changes in the histological sections of the kidney of fish varying dietary doses of ginger root-powder could be as a result of tolerability of the dietary supplement to the fish kidneys. This is in agreement with the observation of [46] who found similar result on the kidney of C. gariepinus fed M. oleifera seed meal.

This is corroborated by [48] who observed no damage done to the kidney of broiler chickens fed ginger by product meal.

\section{CONCLUSION}

The present study showed that dietary supplementation with ginger root-powder is encouraging to improve the growth and health of catfish (C. gariepinus) fingerlings, due to the growth promoting and immunostimulation properties. In addition, ginger root-powder has been shown to positively influence the haematological profile of fish. However, ginger root-powder inclusion of $2 \%$ and $3 \%$ are considered dangerous to the fish liver and ginger root-powder dietary supplementation are regarded to be tolerable to the fish kidney. Hence, the study concluded that $1 \%$ ginger root-powder dietary supplementation in cultured $C$. gariepinus could effectively improve the growth, metabolic activities, health profile and survival of the fish. 


\section{ACKNOWLEGMENT}

The authors appreciated the technical support of technicians in the Fish Nutrition laboratory of the Department of Aquaculture and Fisheries Management for his assistance in the proximate analyses of the experimental diets and fish. We thank Mr. Akinduti in the Department of Veterinary Microbiology, FUNAAB for the haematological analysis. The efforts of the members of staff in the Department of Veterinary Pathology laboratory for the preparation of slides and staining techniques on the histopathology are well appreciated and specially, Dr. Ajayi for the photomicrography and interpretation of results. The financial support of the authors is appreciated for the research work.

Conflict of Interests: There are no conflicts of interest.

\section{REFERENCES}

1 Abdelhamid AM, Magouz FI, Salem MFE, Mohammed AA, Mohsen MK. Effect of graded levels of aflatoxin B1 on growth performance, biochemical, chromosomal and histological behavior of Nile tilapia Oreochromisniloticus. Procedure of the $1^{\text {st }}$ Conference on Animal and Fish Production, Mansoura 24 \& 25 September. 2002; pp. 231-250.

2 Alicia E, Toranzo T, Beatriz MOS, Romalde, JL. A review of the main bacterial fish diseases in mariculture system aquaculture. 2005; 246:37-61.

3 Denev SA. Ecological alternatives of antibiotic growth promoters in the animal's husbandry and Aquaculture. Dsc Thesis, Department of Biochemistry, Microbiology, Trakia University, Stara Zagora, Bulgaria. 2008, pp. 294.

4 Raa J, Roerstad G, Ingested R, Robertson B. The use of Immunostimulants to increase resistance of aquatic organisms to microbial infections, In:Shariff IM, Subasingbe RP, Arthur JR, (editors). Diseases in Asian aquaculture: International Fish health section, Manila, Philippines: Asian Fisheries Society. 1992, pp. 3950.

5 Chagas EC, Val AL. Effeito da vitmina $\mathrm{C}$ no ganho de peso e emparametros hematologicos de tambaqui. Pesquisa Agropecuária Brasileira, Brasilia. 2003; 38(3):397-402.

6 Thopon S, Pokethitiyook P, Chalermwat K, Upatham ES, Sahaphong $\mathrm{S}$. Ultrastructural alterations in the liver and kidney of white sea bass, Latescalcarifer, in acute and subchronic cadmium exposure, Environmental Toxicology. 2004; 19:11-19.

7 Athikesavan S, Vincent S, Ambrose T, Velmurugan B. Nickel induced histopathological changes in the different tissues of freshwater fish, Hypophthalmichthys molitrix (Valenciennes). Journal of Environment biology. 2006; 27:391-95.

8 Loganathan K, Velmurugan, B, Hongray HJ, Selvanayagam M, Bhusan PB. Zinc induced histological changes in brain and liver of Labeorohita (Ham.). Journal of Environment biology. 2006; 27:10710

9 Onyeagba RA, Ugboju OC, Okeke CU, Irokas O. Studies on the antimicrobial effects of garlic (Allium sativum), ginger (Zingiberofficinale) and lime (Citrus aurantifolia), African Journal of Biotechnology. 2004; 3:552-554.

10 Akram M, Shah MI, Usmanghan K, Mohiuddinn E, Sami A. Zingiberofficinale Roscoe (A medicinal plant).Pakistan Journal of Nutrition. 2011; 10:399-400.

11 Murray M. The Healing Power of Herbs, $2^{\text {nd }}$ revised edition, Random House USA Inc Publishing Company, New York, United States. 1995; pp. 432.

12 Chang Y, Liu Wu C, Chiang C, Lian J, Hsieh S. Dietary administration of zingerone to enhance growth, non -specific immune response and resistance to Vibrio alginolyticus in Pacific white shrimp (Litopenaeus vannamei) juveniles. Fish and Shellfish Immunology. 2012; 32:284-290.

13 El-desouky H, El-Asely A, Shaheem AA, Abass A. Effects of Zingiber officinale and Cyanodon dactylon on the Growth Performance and Immune Parameters of Macrobranchium rosenbergii. World Journal of Fish and Marine Science. 2012; 4(3):301-307.

14 Nya EJ, Austin B .Use of dietary ginger, Zingiber officinale. Rosoe, as an immunostimulant to control Aeromonas hydrophila infections in rainbow trout, Oncorhynchusmykiss (Walbaum). Journal of Fish Disease. 2009; 32:971-977.

15 Haghighi M, Rohani MS. The effect of powered ginger (Zingiberofficinale) on the haematological and immunological parameters of rainbow trout Oncorrrhychusmykiss. JMPHTR. 2013; $1: 8-12$.

16 AOAC. Association of International Official Analytic Chemists, AOAC International, $18^{\text {th }}$ edition, Arlington, Virginia. 2011.

17 Klontz GW, Smith LS. Methods of using Fish as biological research subjects. In methods of animal experimentation vol. iii (editor W. I. Grey), Academic Press, New York. 1986, pp. 323-383.

18 Blaxhall PC, Dasley KW. Routine haematological methods for use with fish blood. Journal of Fish Biology. 1973; 5:771-781.

19 Ivanova NT. Atlas of Fish Blood cells, LPP, Moscow, Russia. 1983. ISBN: 19832225035. pp. 80.

20 Haghighi M. Laboratory methods of fish haematology, aquaculture science publications, Tehran, Iran. 2010, pp. 29-71.

21 Dacie JV, Lewis SM. Practical Haematology $9^{\text {th }}$ Edition, Churchill Livingstone, London. 2001, pp. 633.

22 Samuelson A. Textbook of Veterinary Histology, Elsevier Health Sciences Publishing Company, London, United Kingdom. 2007, pp. 560.

23 Agbebi OT, Lawal HB, Odebiyi VC. Aflatoxin effect of moulded gel wastemixed with ginger and its histopathological study on Clarias garepinus. Global Journal of Science Frontier research. 2012; 12 (1):7-15

24 Duncan DB. Multiple ranges and Multiple F-tests Biometrics. International Biometric Society. 1955; 11:25-40.

25 Adekoya BB, Olunuga OA, Ayansanwo TO, Omoyinmi GAK. Manual of the second annual seminar and training workshop held at Ogun State Agricultural Development Programme, OGADEP, OlabisiOnabanjo way, Idi-Aba, Abeokuta. Publisher: Fisheries Society of Nigeria (Ogun State Chapter). 2004, pp. 52.

26 Omotayo AM, Akegbejo-Samson Y, Olaoye OJ. Fish Production, preservation, processing and storage, Training manual of the 2006 Joint training of fish farmers in Epe, Lagos State Agricultural media Resources and Extension Centre (AMREC), Federal University of Agriculture Abeokuta, Ogun State and BATN Foundation, Victoria Island, Lagos. 2006, pp. 19-20.

27 Bello OS, Emikpe BO, Olaifa FE. The body weight changes and gut morphometry of Clarias gariepinus juveniles on feeds supplemented with Walnut (Tetracarpidium conophorum) Leaf and Onion (Allium сера) Bub Residues. International Journal of Morphology. 2012; 30(1):253-251.

28 Karangiya VK, Savsani HH, Shrikant SP, Garg DD, Murthy KS, Ribadiya NK, Vekariya SJ. Effect of dietary supplementation of garlic, ginger and their combination on feed intake, growth performance and economics on commercial broilers, Vet World, 2016; 9(3):245-250

29 Obasa SO, Faturoti EO. Growth response and serum component and yield of the African bony tongue (Heterotisniloticus) fed varying dietary crude protein level, ASSET Series A. 2001; 1(2):97-104.

30 Muhammad-Jameel AK, Sohail HK, Salma M, Syeda SG, Jamila S, Farouq H, Mehdi H, Muhammad A. Effect of Dietary supplementation of Aloe veraleaves on growth performance and immunity of Fayoumi Chicks. Pakistan Journal of Nutrition. 2014. 13 (4):191-195

31 Heidarieh M, Mirvaghefi AR, Sepahi A, Shiekhzadeh N, Shahbazfar AA .Effects of dietary Aloe Vera on growth performance, skin and 
Gastrointestine Morphology in Rainbow trout, Oncorhynchusmykiss. Turkish Journal of Fisheries and Aquatic Sciences. 2013;13: 361373.

32 Onibi GE, Adebisi O E, Fajemisin AN, Adetunji AV. Response of broiler chickens in terms of performance and meat quality to garlic (Allium sativum) supplementation, African Journal of Agricultural Research. 2009; 4(5):511-517.

33 Abdel-Rahman AM. Antagonism of Aeromonas hydrophila by propolis and its effect on the performance of Nile tilapia, Oreochromis niloticus, Fish Shellfish Immunology. 2009; 27:454459.

34 Zomrawi WB, Abdel-Atti KHA, Mahala AG. Effect of ginger root powder supplementation on broiler chick performance, blood and serum constituents. Journal of Animal and Feed Research. 2011; 1(6):457-460.

35 De silva SS. Performance of Oreochromis niloticus fry maintained on mixed feeding schedules of different protein levels. Aquaculture and Fisheries. 2001; 16:621-633.

36 Abou-zeid SM. The effect of some medical plant on reproductive and productive performance of Nile tilapia, Oreochronis niloticus. Ph.D Thesis Cairo, Faculty of Agriculture, Cairo University. 2002, pp. 212.

37 Farah A, Kasiri M, Sudager M, Soleiman I M, Zorrieh-Zahra SMJ. Effect of dietary supplementation of Mellisa officinalis and Aloe vera on haematological traits, lipid oxidation of carcass and performance in rainbow trout (Oncorhynchusmykiss). Journal of Animal and Feed Research. 2012; 2(1):01-05.

38 Ashade OO, Adelusi OE, Ligali NA. Histopathological effects of untreated ginger peel (Zingiber officinale) fish meal on the intestine tissue profiling of African catfish (Clarias gariepinus). International Journal of Fisheries and Aquatic Studies. 2014; 2:95-98.

39 Oyawoye EO, Ogunkunle M. Physiological and biochemical effects of raw Jack beans on broilers, Proceedings of Annual Conference, Nigeria Society of Animal Production. 1998; 23:141-142.

40 Isidahomen CE. Effect of diets containing supplements of ginger (zingiberofficinale) and vitamin c on body weight, haematology and blood serum components in cocks, Nigerian Journal of Agriculture, Food and Environment. 2016; 12(2):162-165.

41 Schaperclaus W. Fish diseases. Oxonian Press Pvt. Ltd., New Delhi, 1991; 2:1398.
42 Douglas JW, Jane KW. In Schalm's Veterinary Haematology. John Willey and Sons, Blackwell Publishing Ltd. 2001.pp. 1232

43 Sotolu AO, Faturoti EO. Growth performance and haematology of Clarias gariepinus fed varying inclusions of Leucaena leucocephala leaf meal. Revista UDO Agricola. 2009; 9(4):979-985.

44 Dienye HE, Olumuyi OK. Growth performance and haematological responses of African mud catfish Clarias gariepinus fed dietary levels of Moringa oleifera leaf meal. Net Journal of Agricultural Science. 2014; 2(2):79-88.

45 Rapatsa MM, Moyo NAG. Effect of Moringer oleiferaon the histology, haematology and growth of Oreochromis mossambicusin aquadams fertilized with chicken manure in South Africa. African Journal of Aquatic Science. 2014; 39(3):295-303.

46 Bamidele NA, Obasa SO, Ikeiwenwe NB, Abdulraheem I, Adeoye AA, Odebiyi OC. Effect of dried moringa (Moringa oleifera) seed meal based diet on the growth, haematological, biochemical parameter and histopathology of African catfish, Clarias gariepinus fingerlings. International Journal of Fisheries and Aquatic Studies. $2015 ; 2: 27-34$.

47 Szende B, Suba Z. Introduction to Histopathology, Medicinal Publishing, Budapest. 1999, pp. 292.

48 Daudo OM. Effect of ginger by-product meal supplementation with Enzyme/Palm oil on performance, blood chemistry and histopathology of broiler chickens. PhD Thesis, Ahmadu Bello University, Zaria, Nigeria. 2012, pp. 205.

\section{How to cite this article:}

Ibidunni AS, Olubodun OS, Ikililu A. Metabolic activities and health indices of African catfish (Clarias gariepinus) fed varying levels of Zingiber officinale root. J App Biol Biotech. 2017; 5 (04): 021-028. 